\title{
Human footprints in Pleistocene volcanic ash
}

\author{
These ancient tracks are the oldest known to have been made by fully bipedal humans.
}

W ways of human footprints in a zeolite-rich pyroclastic flow dated to 385,000-325,000 years ago (kyr), discovered along the western margin of the Roccamonfina volcanic complex in southern Italy. We believe that these tracks are the oldest human footprints found so far and that they were made by hominids who had a fully bipedal, free-standing gait, using their hands only to steady themselves on the difficult descent.

Known locally as 'devils' trails' (and pointed out to us by Marco De Angelis and Adolfo Panarello), the three human trackways are associated with other mammalian tracks in a Middle Pleistocene pyroclastic flow known as the Brown Leucitic Tuff, from the Roccamonfina volcano in northwestern Campania, southern Italy.

The stratigraphic location and age of the e have analysed three fossilized track-

trampled layer are supported by lithological comparison with the well-documented radiometric-dated series of the volcanic complex ${ }^{1}$. The development of the Roccamonfina volcano can be divided into three main phases ${ }^{2}$ : the first, eruptive phase (630-385 kyr), which ended with a calderaforming event; a second in which volcanic-tectonic events formed the Brown Leucitic Tuff (385-325 kyr) as well as later pyroclastic flow units; and a third that saw the formation of trachybasaltic lavas and ended about 50,000 years ago.

The tracks (designated here as A, B and C) occur on the surface of a single pyroclastic flow unit that probably belonged to the second phase, and they descend a steep slope that is inclined by up to $80^{\circ}$. The tracks have the same general direction but different stride patterns.

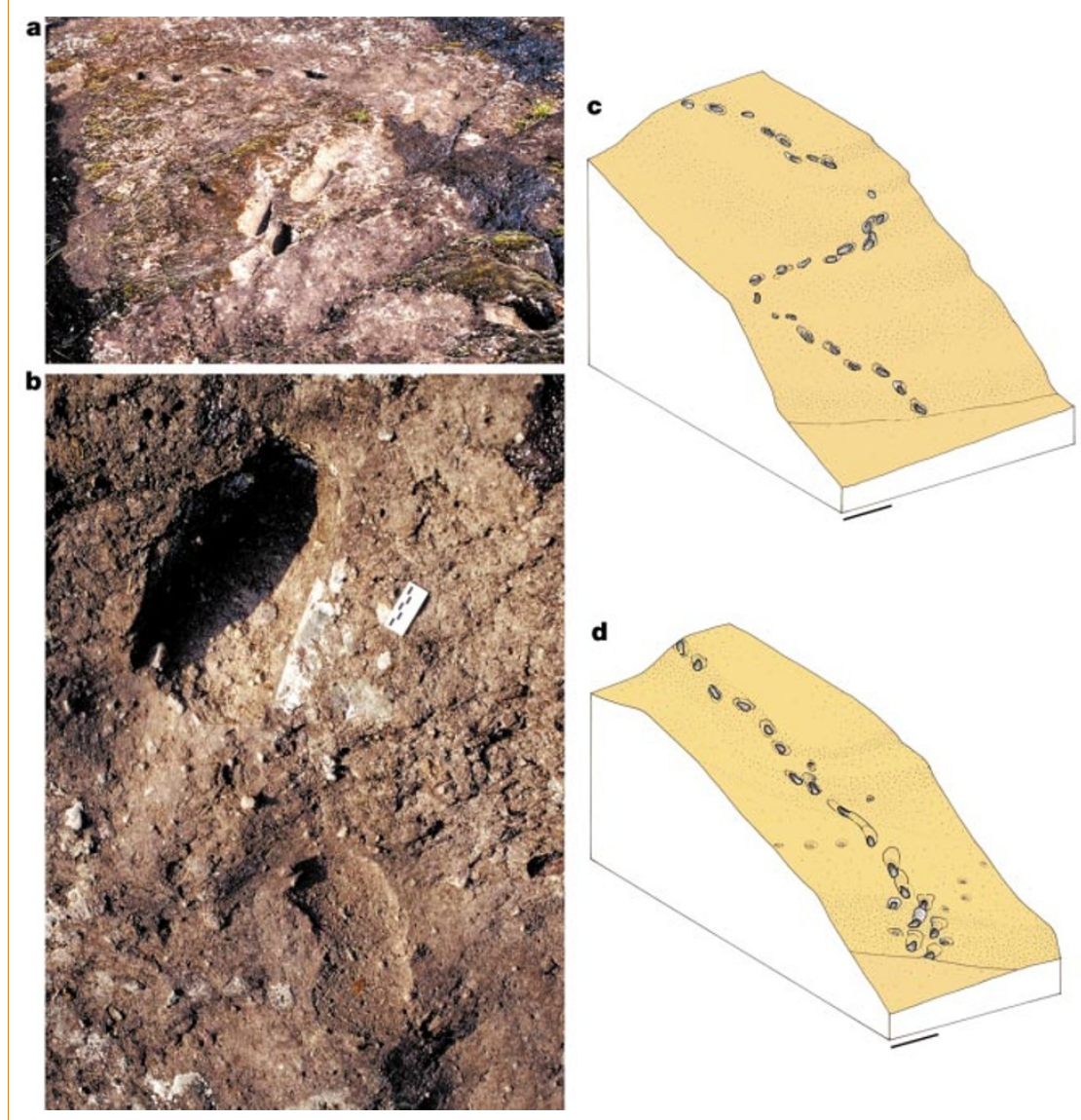

Figure 1 Middle Pleistocene human tracks from the Brown Leucitic Tuff at the Roccamonfina volcano in northwestern Campania, southern Italy. $\mathbf{a}, \mathbf{b}$, Views of the western part of the site showing trail A, which descends an inclined slope (detail enlarged in $\mathbf{b}$ ). $\mathbf{c}, \mathbf{d}$, Diagrams of trackways A and B, respectively. The trackways indicate the course taken by the trackmaker and therefore his or her direction with respect to the slope. On either side of the final two footprints in trackway B, and also about halfway along it, handprints are evident that probably result from attempts to maintain balance during the difficult descent. Scale bars, $1 \mathrm{~m}$
Trackway A is $13.40 \mathrm{~m}$ long and consists of 27 footprints across a difference in elevation of $4.26 \mathrm{~m}$; the slope is crossed by a Z-shaped trackway that contains two sharp turns, presumably made in order to negotiate the descent more easily (Fig. $1 \mathrm{a}-\mathrm{c}$ ).

Trackway B is $8.60 \mathrm{~m}$ long and consists of 19 footprints over a difference in elevation of $2.91 \mathrm{~m}$; the slope is crossed in a single straight line that curves roughly $45^{\circ}$ to the right (Fig. 1d). The footprints are less evenly spaced after the fifth footprint, as a steeper section is negotiated, and there is evidence of slipping: an occasional handprint is seen on the slope beside the track, placed with an open palm at the side of the trunk (Fig. 1d). By contrast, trackway C (not shown) follows a straight line of $9.98 \mathrm{~m}$, with 10 regular footprints over a smaller incline of $2.56 \mathrm{~m}$, indicating a constant pace with no slipping.

The footprints are about $20 \mathrm{~cm}$ in length and $10 \mathrm{~cm}$ in width. Using the global average foot-length/stature ratio of $15 \%$, the footprints indicate that the people who made them were no taller than $1.5 \mathrm{~m}$. In some of the prints, the impressions made by the heel and ball of the foot are clear, and there are even small depressions that can be interpreted as toe impressions. The ball impressions have oblique principal axes that run anteromedially to what is thought to be the base of the big toe. In some cases, the central area of the footprint is raised, indicating that the foot was arched. The trackways are narrow, with an average pace of $60 \mathrm{~cm}$ and a stride of $120 \mathrm{~cm}$. Although the footprints do not show all of the known features of contouring human bipedalism, there are enough similarities to support the idea that they are indeed human and fully bipedal ${ }^{3}$.

Although the dating of these trackways is provisional, to our knowledge they are the first human tracks discovered from the Middle Pleistocene period and are therefore the oldest to be found so far.

Paolo Mietto ${ }^{\star}$, Marco Avanzini $\dagger$, Giuseppe Rolandi $\ddagger$

${ }^{\star}$ Dipartimento di Geologie, Paleontologie e Geofisica, Università di Padova, 35137 Padova, Italy e-mail:paolo.mietto@unipd.it

$†$ Museo Tridentino di Scienze Naturali, 38100 Trento, Italy

$\ddagger$ Dipartimento di Geofisica e Vulcanologia,

Università di Napoli-FedericoII,

80138 Napoli, Italy 1. Ballini, A., Barberi, F., Laurenzi, M. A., Mezzetti, F. \&
Villa, I. M. Bollettino Gruppo Nazionale di Vulcanologia 5,
533-574 (1989).

2 De Rita, D., Giordano, G. \& Milli, S. J. Volcanol. Geotherm. Res. 78, 2267-2288 (1996)

3. Kramer, P. A. \& Eck, G. C. J. Hum. Evol. 38, 651-666 (2000). Competing financial interests: declared none. 